\title{
European Communities - Conditions for the Granting of Tariff Preferences to Developing Countries (WT/DS246/AB/R)
}

\author{
GENE M. GROSSMAN \\ Princeton University \\ ALAN O. SYKES \\ University of Chicago
}

\section{Introduction}

The WTO case brought by India in 2002 to challenge aspects of the European Communities' Generalized System of Preferences (GSP) brings fresh scrutiny to a policy area that has received little attention in recent years - trade preferences for developing countries. The idea for such preferences emerged from the first United Nations Conference on Trade and Development (UNCTAD) in 1964. The ensuing negotiations led to Resolution 21(ii) at the second session of UNCTAD in 1968, acknowledging "unanimous agreement" in favor of the establishment of preferential arrangements. ${ }^{1}$ Tariff discrimination violates the most-favored nation (MFN) obligation of General Agreement on Tariffs and Trade (GATT) Art. I, however, and thus the legal authority for preferential tariff schemes had to await a GATT waiver of this obligation, which came in 1971. The waiver was to expire after 10 years, but the authority for preferences was extended by the GATT Contracting Parties Decision of November 28, 1979 on Differential and More Favorable Treatment, Reciprocity and Fuller Participation of Developing Countries, popularly known as the "Enabling Clause,", and now incorporated into the law of the WTO along with the GATT itself.

\footnotetext{
${ }^{1}$ See OECD Secretary General (1983). $\quad{ }^{2}$ GATT, 26th Supp. BISD 203 (1980).
} 
While trade discrimination favoring developing countries is the essence of any GSP scheme, India's WTO complaint raised the question of what type of discrimination is permissible - must all developing countries be treated alike, or can preference-granting nations discriminate among them based on various sorts of criteria? The European system challenged by India afforded more generous preferences to the least-developed countries, to developing nations that undertook certain measures to protect the environment and labor rights, and to 12 nations involved in efforts to combat drug trafficking. India originally challenged the environmental, labor and drug-related preferences, but later limited its complaint to only the drug preferences. A WTO Panel ruled in India's favor in late 2003. ${ }^{3}$ The WTO Appellate Body affirmed the ruling in India's favor in early $2004,{ }^{4}$ although it modified the Panel's findings in a way that seemingly authorized some differential treatment of developing countries based on their "development, financial and trade needs."

The purpose of this chapter is to review the current state of the law in the WTO system, and to ask whether economic analysis can offer any wisdom about the proper extent of "discrimination" through GSP measures. As shall become clear, the issues are challenging ones, both from a legal and an economic standpoint. There are good economic reasons to be concerned about discrimination and reciprocity in GSP schemes, and respectable legal arguments that they should be strictly limited. GSP benefits are "gifts" of a sort, however, and tight limitations on their terms may put an end to them altogether. It is exceedingly difficult to say whether discrimination and reciprocity in GSP schemes make the trading community worse off or better off over the long haul.

Section 2 of this chapter provides a legal and a historical background, including a description of the GSP schemes currently in place in the United States and Europe, and a thorough review of the recent Panel and Appellate Body decisions. Section 3 evaluates the Appellate Body decision from a legal perspective and considers its possible implications for aspects of the US and European GSP schemes that were not challenged by India. Section 4 examines trade preferences from an

3 European Communities - Conditions for the Granting of Tariff Preferences to Developing Countries, WT/DS246/R (December 1, 2003) (hereafter Panel Rep.).

4 European Communities - Conditions for the Granting of Tariff Preferences to Developing Countries, WT/DS246/AB/R (April 7, 2004) (hereafter AB Rep.). 
economic perspective, inquiring into the soundness of the GSP concept as a whole and asking whether some forms of "discrimination" are somehow better than others.

\section{Legal background}

Resolution 21(ii) at UNCTAD II in 1968 called for the establishment of a "generalized, non-reciprocal, non-discriminatory system of preferences in favour of the developing countries, including special measures in favour of the least advanced among the developing countries." It further stated that such preferences had three objectives: to increase the export earnings of developing countries, to promote their industrialization, and to accelerate their rates of economic growth.

From the outset of serious negotiations within UNCTAD, however, it was clear that the "non-discriminatory system of preferences" envisioned by Resolution 21(ii) would in fact embody considerable elements of "discrimination." Indeed, Resolution 21(ii) on its face contemplates discrimination in favor of the least-developed countries. Further, the theory behind GSP was that it would reduce the reliance of developing countries on exports of primary products and promote industrialization. Accordingly, it was understood that manufactured goods would be the main beneficiaries of preferences, and that agricultural products would be treated less favorably. ${ }^{5}$ This "discrimination" across sectors inevitably produces a kind of de facto discrimination across beneficiaries - some beneficiaries have far greater capacity to produce the manufactured goods that are designated for preferential treatment than others.

Beyond these features built into the conception of the system, political factors intruded heavily on the willingness of nations to grant preferences across the board. Some developing countries were seen as ideologically unacceptable recipients of preferences, many produced manufactured goods in politically sensitive import sectors such as textiles and footwear, and the possibility of import surges was a matter of significant concern. Thus, it quickly became clear that if GSP schemes were to be politically viable in the major developed nations, they would have to contain substantial additional limitations as to product coverage and beneficiaries, and be accompanied by safeguards to address

\footnotetext{
${ }^{5}$ See OECD Secretary General (1983).
} 
politically unacceptable increases in imports. No mechanism existed for coordinating the evolution of national schemes on such matters, and thus each developed rather differently.

Along the way, some preference-granting countries began to condition GSP benefits on the willingness of beneficiary nations to cooperate on various policy margins, either by rewarding cooperation with greater preferences or punishing its absence by withdrawing them. The conception of GSP as a "non-reciprocal" program thus came under considerable pressure as well.

\subsection{GSP scope and conditionality in the United States and Europe}

UNCTAD reports that there are currently 16 national GSP schemes notified to the UNCTAD secretariat - Australia, Belarus, Bulgaria, Canada, the Czech Republic, the European Community, Hungary, Japan, New Zealand, Norway, Poland, the Russian Federation, the Slovak Republic, Switzerland, Turkey, and the United States. ${ }^{6}$ They differ in significant detail, and interested readers may consult the UNCTAD website for the particulars of various systems. Our purpose here is simply to show how the more important schemes are riddled with provisions that might be viewed as "discrimination" or "reciprocity," and for that purpose it will suffice to consider only the schemes of the United States and the European Communities.

\subsubsection{GSP in the United States}

The GSP of the United States was first enacted in the Trade Act of 1974 and took effect in 1976. It is presently authorized through 2006 and will then expire unless renewed by an act of Congress.

The statute has three sections - a general grant of authority to the President to extend preferences, ${ }^{7}$ a section on the designation of beneficiary countries, ${ }^{8}$ and a section on the designation of eligible products. ${ }^{9}$ Regarding the designation of beneficiary countries, the statute begins with a short list of developed countries that are ineligible. It next forecloses beneficiary status to eight other categories of nations: (1) "communist" countries (with exceptions); (2) countries

\footnotetext{
${ }^{6}$ See http://www.unctad.org/Templates/Page.asp?intItemID=2309\&lang=1, last accessed September 1, 2004.

${ }^{7} 19$ U.S.C. $\S 2461 . \quad{ }^{8} 19$ U.S.C. $\S 2462 . \quad{ }^{9} 19$ U.S.C. $\S 2463$.
} 
that are parties to an "arrangement" which withholds "supplies of vital commodity resources from international trade" (aimed at OPEC); (3) countries that injure US commerce by affording preferences to other developed countries; (4) countries that expropriate the property of US citizens, including intellectual property, without just compensation; (5) countries that fail to enforce binding arbitral awards in favor of US citizens; (6) countries that aid or abet terrorism or fail to take "steps to support the efforts of the United States to combat terrorism";

(7) countries that have not taken steps "to afford internationally recognized worker rights"; and (8) countries that fail to fulfill their "commitments to eliminate the worst forms of child labor." The last five exclusions can be waived by the President in the "national economic interest." 10

The President has the discretion to confer beneficiary status on any nation not excluded by the above factors, and the statute provides additional factors that the President must take into account in exercising this discretion. ${ }^{11}$ The President must consider, along with the prospective beneficiary's interest in the program, its level of development, and its treatment in the GSP schemes of other donor countries, whether the country provides "equitable and reasonable access to [its] markets and basic commodity resources" and "adequate and effective protection of intellectual property rights," whether it has taken steps to reduce investment-distorting practices and barriers to trade in services, and whether it takes steps to afford internationally recognized worker rights. The statute also provides for "mandatory graduation" of "high income" countries, without defining the term "high income." 12 At the low-income end of the spectrum, it also allows the President to designate least-developed beneficiary nations, and to extend to them preferences that are not extended to other developing nations.

Pursuant to these provisions, quite a number of nations that have become highly successful exporters, such as Hong Kong, Singapore, and Malaysia, have now been "graduated" from the US scheme due to their "high-income" status. Several nations have had their GSP status suspended temporarily due to problems in their worker-rights practices, including Nicaragua, Paraguay, and Chile. Some of the benefits to Argentina were suspended in 1997 over an intellectual property

${ }^{10} 19$ U.S.C. $\S 2462(b) . \quad{ }^{11} 19$ U.S.C. $\S 2462(c) . \quad{ }^{12} 19$ U.S.C. $\S 2462(e)$. 
dispute, and some of the benefits to Pakistan were suspended at one time but later restored in return for cooperation in anti-terror efforts. Beneficiary status has also been denied to a number of nations with whom the United States has had poor political relations (e.g. Cuba, Iran, North Korea, Syria). ${ }^{13}$ It is assuredly possible that geopolitical considerations play a broader role sub rosa in many of the decisions regarding beneficiary status, and there is no mechanism to ensure that the various criteria are applied in careful and even-handed fashion.

We will not dwell at length on the provisions for the designation of eligible products, as they are unlikely to be at the heart of any dispute over "discrimination" or "reciprocity" (although they might be said to cause de facto discrimination as indicated). Because they are relevant to an assessment of the economic effects of the system, however, we note three important details. First, many sensitive items are excluded by statute from the GSP system, such as certain textile and apparel products, watches, electronic products, steel products, footwear and leather products, certain agricultural products, and "any other articles which the President determines to be import-sensitive." 14

Second, a product from a particular beneficiary becomes ineligible for coverage if there is no longer a "competitive need" (unless it comes from a least-developed beneficiary). When imports of a product from a single beneficiary exceed a certain monetary threshold (currently $\$ 115$ million), or $50 \%$ of all US imports of the article in a calendar year, it must be removed as an eligible product unless the President executes a "waiver." 15

Third, all items are subject to rules of origin. In general, a product will not be deemed to originate in a beneficiary nation unless it meets a 35-percent value-added test - the value of the input products produced in the beneficiary nation, plus the value of processing in that nation, must equal $35 \%$ of the value of the finished good. ${ }^{16}$

\subsubsection{GSP in the European communities}

The European approach to GSP has evolved considerably over time. The system in place through 1994 relied heavily on quantitative limits

13 See generally UNCTAD, Generalized System of Preferences: Handbook on the Scheme of the United States of America (2003); UNCTAD, Generalized System of Preferences: List of Beneficiaries (2001).

1419 U.S.C. $\S 2463(\mathrm{~b}) . \quad{ }^{15} 19$ U.S.C. $\S 2463(\mathrm{c}-\mathrm{d}) . \quad{ }^{16} 19$ U.S.C. $\S 2463(\mathrm{a})(2)$. 
for the importation of duty-free or reduced-duty industrial and agricultural products. The arrangement challenged by India, which is now authorized through the end of 2005 , relies to a much greater extent on "tariff-modulation" and "special-incentive" arrangements, coupled with provisions for country and sectoral graduation as well as an "everything-but-arms" arrangement for least-developed countries. ${ }^{17}$

The tariff-modulation arrangement classifies goods into "verysensitive," "sensitive," "semi-sensitive," and "non-sensitive" products. Roughly speaking and with a few exceptions, beneficiary countries then receive tariff reductions of $15 \%, 30 \%, 65 \%$, and $100 \%$, respectively, off the usual MFN rate for goods in each category. Least-developed countries, however, receive duty-free treatment on goods in all categories except armaments. Countries can be completely graduated from the system based on a "development index," and individual exports from particular countries can also be graduated based on a combination of considerations relating to the development index and to the beneficiary's market share or degree of specialization in a particular product.

"Special-incentive arrangements" provide additional margins of preference to nations that apply for them and prove their eligibility. A labor arrangement applies to developing countries that have adopted the substance of the standards required by several International Labor Organization Conventions relating to, inter alia, forced labor, collective bargaining rights, non-discrimination principles, and child labor. An environmental-incentive arrangement applies to goods originating in countries with tropical forests that can establish their adherence to international standards regarding the sustainable management of tropical forests.

The special arrangements supporting measures to combat drugs are made available to 11 South or Central American countries, plus Pakistan, that are involved in efforts to reduce drug trafficking. They too provide additional margins of preference on a range of products, essentially exempting goods from sector-specific graduation rules that would otherwise apply to them.

${ }^{17}$ See generally Council Regulation (EC) No. 250/2001 of 10 December 2001 applying a scheme of generalized tariff preferences for the period from 1 January 2002 to 31 December 2004; UNCTAD, Generalized System of Preferences: Handbook on the Scheme of the European Community (2002). 
Finally, the scheme contains a number of "temporary-withdrawal and safeguard" provisions. The most important are aimed at import surges, and allow preferences to be suspended after an investigation of such developments. Other provisions for temporary withdrawal apply to situations where the beneficiary country has been shown to have tolerated slavery, violated worker rights, exported goods of prison labor, failed to take appropriate means to control drug trafficking, engaged in fraud with respect to rules of origin, engaged in "unfair trade practices," or infringed on the objectives of certain fishery conventions.

The policies favored by the European system differ somewhat from the policies encouraged by the United States, although there are notable similarities. Both systems certainly exhibit a significant degree of "discrimination" and "reciprocity" in their design and in their application that goes well beyond simply the more favorable treatment of least-developed nations that was envisioned by UNCTAD Resolution 23(ii).

\subsection{India's complaint and its legal basis}

As noted earlier, India's original complaint before the WTO challenged the labor, environmental, and drug-related preferences in the European GSP scheme, but India later restricted its challenge to the drug-related preferences. Its decision to restrict the scope of its complaint has resulted in an Appellate Body decision that leaves open many questions about the permissible scope of "discrimination," as shall be seen.

The legal foundation for India's challenge begins with GATT Art. I, which requires that any "advantage, favour, privilege or immunity" granted by one member nation to the product of another and relating, inter alia, to "customs duties and charges of any kind," must also be granted "immediately and unconditionally" to like products originating in other member nations. This principle is commonly termed the "most-favored nation" (MFN) obligation of GATT.

Any GSP scheme, of course, involves tariff discrimination by the preference-granting nation. It thus requires some derogation from the legal prohibition in Art. I, which was first allowed under a 10-year waiver approved by the GATT membership in 1971. During the Tokyo Round, however, GATT members negotiated an agreement to make the authority permanent, embodied in the so-called "Enabling Clause." 
The relevant text of the Enabling Clause provides:

1. Notwithstanding the provisions of Article I of the General Agreement, contracting parties may accord differential and more favourable treatment to developing countries, without according such treatment to other contracting parties.

2. The provisions of paragraph 1 apply to the following:

(a) Preferential tariff treatment accorded by developed contracting parties to products originating in developing countries in accordance with the Generalized System of Preferences, ${ }^{3 \text { (original }}$ footnote) ....

(d) Special treatment of the least developed among the developing countries in the context of any general or specific measures in favour of developing countries.

3. Any differential and more favourable treatment provided under this clause:

(a) shall be designed to facilitate and promote the trade of developing countries and not to raise barriers to or create undue difficulties for the trade of any other contracting parties;

(b) shall not constitute an impediment to the reduction or elimination of tariffs and other restrictions to trade on a most-favoured-nation basis;

(c) shall in the case of such treatment accorded by developed contracting parties to developing countries be designed and, if necessary, modified, to respond positively to the development, financial and trade needs of developing countries.

3(original footnote) As described in the Decision of the CONTRACTING PARTIES of 25 June 1971 , relating to the establishment of "generalized, non-reciprocal and non discriminatory preferences beneficial to the developing countries."

The Enabling Clause plainly allows nations to depart from the MFN obligation to provide more favorable tariff treatment to goods from developing countries, and to provide even more favorable treatment for goods from the least-developed countries. Its text is otherwise silent on the range of goods to be covered by preferences, on the permissibility of other forms of "discrimination" among beneficiaries, and on the acceptability of attaching conditions ("reciprocity") to preferential benefits. Footnote 3, however, states that the 
"Generalized System of Preferences" contemplated by the Enabling Clause is the system contemplated in the 1971 waiver, which in turn referred back to the "generalized, non-reciprocal, and nondiscriminatory" system of preferences discussed under the auspices of UNCTAD.

Footnote 3 raises a number of issues not directly addressed by India's complaint. What is meant by the requirement of "generalized" preferences - does this obligation place any limits on the exclusion of particular products from GSP schemes? What does the obligation to provide "non-reciprocal" preferences imply about the imposition of conditions for the granting of preferences?

India's complaint put these issues to the side and focused instead on the requirement of non-discriminatory preferences. According to India, when a nation grants a preference on a particular product, it must extend that preference to all developing countries, subject only to the proviso that least-developed nations can receive greater preferences. Because the drug-related preferences in the European scheme afford special benefits to 12 enumerated beneficiaries that are not co-extensive with the set of least-developed nations, India contended, the preferences failed the requirement of non-discrimination under the Enabling Clause and in turn violated GATT Art. I.

\subsection{The European response and the Panel decision}

Before the Panel, Europe's first response was a formalistic claim that the Enabling Clause did not create an exception to Art. I of GATT, but removed GSP schemes altogether from the coverage of Art. I. The distinction was important, according to Europe, because India's complaint alleged a violation of Art. I but not of the Enabling Clause per se, and the Panel should only adjudicate claims brought before it. The Panel quickly put this issue to the side (over a dissent), however, and read the Enabling Clause as an exception to the MFN obligation of Art. I - but for the exception, preferences would violate Art. I, and therefore India's allegation of an Art. I violation squarely raised the proper issue. Further, following WTO precedent on "exceptions" to primary obligations, the Panel held that Europe had the burden of demonstrating that its program fell within the exception afforded by the Enabling Clause. ${ }^{18}$

\footnotetext{
${ }^{18}$ Panel Rep. $₫ \uparrow 7.31-7.54$.
} 
Once the Panel ruled that GSP preferences fell under Art. I, the Panel had little difficulty in concluding that India made out a prima facie case of a violation. ${ }^{19}$ The Panel then turned to the question whether Europe could invoke the Enabling Clause and thereby establish its "affirmative defense." On this front, Europe had three main arguments. First, it pointed to paragraph 3(c) of the Enabling Clause, which provides that differential treatment shall "be designed and, if necessary, modified, to respond positively to the development, financial and trade needs of developing countries." Europe argued that different developing countries have different "development, financial and trade needs," and that this provision authorized (and indeed required) preferences to be modified to respond to those differing needs, inevitably producing differences in the preferences across beneficiaries.

Second, Europe argued that India misinterpreted the requirement in footnote 3 that preferences be "non-discriminatory." For Europe, "discrimination" involved arbitrary differences in the treatment of similarly situated entities - as long as differences in treatment could be justified by a legitimate objective, and the differences were reasonable in pursuit of that objective, no "discrimination" should be found. ${ }^{20}$

Third, Europe argued that paragraph 2(a) of the Enabling Clause, which authorizes "preferential tariff treatment accorded by developed contracting parties to products originating in developing countries," did not require preference-granting nations to afford preferences to all developing countries. Had the drafters meant to require that preferences be extended to all, Europe suggested, they could have inserted the word "all" into the text.

India's response to the first and third arguments was that the term "developing countries" in paragraphs 3(c) and 2(a) should be read as all developing countries, i.e. developing countries as a group. Preferences should respond to the "development, financial, and trade needs" of those countries as a group, claimed India, and should not vary in accordance with any individual needs. In India's view, paragraph 2(a) likewise provided no authority for picking and choosing among developing countries. This proposition is reinforced by footnote 3 and its reference to non-discriminatory preferences, according to India,

${ }^{19}$ Panel Rep. $\uparrow \Upsilon 7.55-7.60$.

${ }^{20}$ Robert Howse advances another line of argument that Europe did not pursue in the case. He suggests that the "obligations" in footnote 3 , particularly the obligation to afford "non-discriminatory" preferences, were never intended to have binding legal effect but were merely aspirational. For a thorough vetting of this perspective, see Howse (2003). 
which should be read to require formally identical treatment subject only to the exceptions specifically contemplated by the Enabling Clause.

The Panel addressed each of Europe's arguments separately, but its analysis of all three was strikingly parallel. The Panel found that the relevant portions of the text of the Enabling Clause were ambiguous. Following the Vienna Convention, it then turned to the context of the treaty text, its object and purpose, and other aids to interpretation. It noted that the Enabling Clause referred back to the waiver granted in 1971, which in turn made reference to "mutually acceptable" preferences. The "mutually acceptable" preferences were apparently those negotiated under the auspices of UNCTAD and embodied in the "Agreed Conclusions" that eventually emerged from the ongoing negotiations in UNCTAD. The Panel thus concluded that the Enabling Clause should be interpreted to permit the sort of preferential system contemplated by the UNCTAD negotiators, memorialized in the Agreed Conclusions, and incorporated by implicit reference into the 1971 waiver.

The Panel then reviewed the Agreed Conclusions at some length. It found that they anticipated some limitations on product coverage most manufactured goods would be covered, with limited exceptions, with only case-by-case coverage for agriculture. But, according to the Panel, nothing in the negotiating history seemed to contemplate discrimination among developing countries on the basis of their development or other "needs," except for the special treatment of leastdeveloped nations. The only other potential limitations on coverage addressed by the UNCTAD negotiations concerned measures to withdraw preferences or to set quantitative ceilings when exporters achieved a certain competitive level, along with safeguard measures to address import surges.

On the basis of these findings, the Panel accepted India's suggestion that the phrase "developing countries" in paragraph 2(a) referred to all developing countries, ${ }^{21}$ and implicitly as well its suggestion that the reference to "developing countries" in paragraph 3(c) was to developing countries as a group. According to the Panel, paragraph 3(c) did not authorize differences in preferences except those contemplated by the UNCTAD negotiators. ${ }^{22}$ Finally, the Panel found no basis in the

${ }^{21}$ Panel Rep. $\uparrow 7.174 . \quad{ }^{22}$ Panel Rep. $\uparrow 7.116$. 
text or relevant negotiating history for Europe's suggestion that the requirement of "non-discriminatory" preferences was satisfied as long as differences in treatment resulted from objective criteria relating to legitimate objectives. Rather, footnote 3 "require[d] that identical tariff preferences under GSP schemes be provided to all developing countries without differentiation," excepting only the differential treatment expressly contemplated in the Agreed Conclusions. ${ }^{23}$

Europe's final line of defense was an effort to invoke GATT Art. $\mathrm{XX}(\mathrm{b})$, which allows measures "necessary to protect human ... health." The Panel was not persuaded, questioning whether the drugrelated preferences were genuinely aimed at the protection of human health in Europe, questioning their "necessity," and questioning whether they amounted to an arbitrary discrimination among beneficiary nations where similar conditions prevail in violation of the chapeau to Art. XX. ${ }^{24}$ Europe did not appeal these findings.

\subsection{The Appellate Body decision}

The Appellate Body affirmed the proposition that the Enabling Clause is an exception to GATT Art. I. India had the burden of raising the question whether Europe's system was consistent with the Enabling Clause and did so; Europe then had the burden of proving its consistency.

Europe did not appeal the Panel's interpretation of paragraph 3(c) of the Enabling Clause, as the Panel had not made any explicit "findings" regarding the consistency of the European drug preferences with paragraph $3(\mathrm{c})$. The appeal was thus confined to the question of whether the European system was consistent with paragraph 2(a) and with its footnote 3 requiring "non-discriminatory" preferences. On the latter issue, the Appellate Body found that the ordinary meaning of the term "non-discriminatory" was not sufficiently clear to permit it to choose between the competing views of discrimination put forth by India and the European Communities on that basis. ${ }^{25}$ Both parties agreed that "discrimination" entailed disparate treatment of those "similarly situated," but disagreed on what it meant to be "similarly situated" - and an appeal to the ordinary meaning of the term "discrimination" did not resolve such a disagreement.

${ }^{23}$ Panel Rep. $\left\lceil 7.161 . \quad{ }^{24}\right.$ Panel Rep. $\left\lceil 7.236 . \quad{ }^{25}\right.$ AB Rep. $\uparrow \uparrow 151-52$. 
The Appellate Body then turned to paragraph 3(c) of the Enabling Clause to provide further context for the interpretation of the nondiscrimination obligation, and accepted the European argument that the absence of the word "all" before "developing countries" implied that the text imposed no obligation to treat all developing countries alike. ${ }^{26}$ Further, both parties apparently conceded that the development needs of various countries could differ. Accordingly, the Appellate Body was "of the view that, by requiring developed countries to 'respond positively' to the 'needs of developing countries,' which are varied and not homogeneous, paragraph 3(c) indicate[d] that a GSP scheme may be 'non-discriminatory' even if 'identical' tariff treatment is not accorded to 'all' GSP beneficiaries." ${ }^{27}$ It thus reversed the Panel's finding to the contrary. Likewise, the Appellate Body reversed the Panel's finding that the reference to "developing countries" in paragraph 2(a) was to all developing countries. ${ }^{28}$ It held that preferencegranting countries are permitted to treat beneficiaries differently when such differences "respond positively" to varying "development, financial, and trade needs."

The non-discrimination requirement was not without bite in the view of the Appellate Body, however, because it did require "that identical tariff treatment must be available to all GSP beneficiaries with the 'development, financial [or] trade need' to which the differential treatment [was] intended to respond." ${ }^{29}$ Because there was no specific finding by the Panel regarding the consistency of the European drugrelated preferences with paragraph 3(c), the Appellate Body was prepared to accept arguendo that drug trafficking related to a "development need." Even so, the preferences would still fail the nondiscrimination test unless "the European Communities prove[d], at a minimum, that the preferences granted under the Drug Arrangements [were] available to all GSP beneficiaries that [were] similarly affected by the drug problem." ${ }^{\text {, }}$

The Appellate Body then held that the European Communities failed to carry the burden of proof on this issue. It emphasized that the drug-related preferences were available only to a "closed list" of 12 countries. The regulation creating the preferences did not set out any criteria for the selection of the countries, and it did not provide any

\footnotetext{
${ }^{26}$ AB Rep. $\uparrow 159 . \quad{ }^{27}$ AB Rep. $\mid 165 . \quad{ }^{28}$ AB Rep. $\uparrow 175-76 . \quad{ }^{29}$ AB Rep. $\mid 180$.

${ }^{30} \mathrm{Id}$.
} 
mechanism for adding or deleting countries as their circumstances changed. Under these conditions, Europe failed to demonstrate that its preferences were non-discriminatory.

Along the way, the Appellate Body contrasted the labor and environmental incentive arrangements in the European GSP scheme. Unlike the situation with the drug-related preferences, the regulation creating the labor and environmental incentives provided "detailed provisions setting out the procedure and substantive criteria that apply to a request ... to become a beneficiary under either of those special incentive arrangements." ${ }^{\text {"1 }}$ The Appellate Body thus hinted that those aspects of the European scheme might pass the non-discrimination test if challenged, but did not speak to the concurrent issue of whether the labor and environmental incentives responded to legitimate "development, financial, and trade needs."

\section{Legal commentary}

\subsection{An assessment of the WTO outcome}

As with most hard cases, it is difficult to say which side was "right" on a purely legal basis. The case is hard because, as both the Panel and the Appellate Body acknowledged, the text of the Enabling Clause is ambiguous. Even assuming that footnote 3 was intended to create a binding non-discrimination obligation, as the parties to the case assumed, the absence of any definition for the concept opens the door to a wide range of interpretations. Any student of civil rights law, constitutional law, or even GATT Arts. I and III is well aware of the fact that "discrimination" is an extremely elastic notion. The phrase "developing countries" in paragraphs 2(a) and 3(c) is equally difficult to pin down. It is surely true, as the Appellate Body noted, that the drafters could have said "all developing countries," but did not. Yet, it is equally true that the drafters might have said "particular" or "selected" developing countries, or used some other phrasing to signify the acceptability of differential treatment, but did not. As always, inferences about the intentions of the drafters from phrasings that they did not employ are questionable at best.

${ }^{31}$ AB Rep. $\Upsilon 182$. 
In the face of such ambiguity, the Panel relied primarily on historical context and the UNCTAD negotiations to give footnote 3 some definitive content. The 1971 waiver referenced in footnote 3 indeed contemplates "mutually acceptable" preferences, and the Agreed Conclusions from the UNCTAD negotiations may well have been a good indicator of what was "mutually acceptable." The Panel was also correct to note that a major impetus for the UNCTAD negotiations was to back away from the historical patchwork of discriminatory preferences already in place in favor of a generalized system of preferences. From these facts, the Panel inferred that any discrimination had to be limited to what was expressly contemplated by the Agreed Conclusions.

The Panel's approach resonates somewhat with an economic perspective on the GSP system that we develop in the next section, and which may help to clarify the object and purpose of the Enabling Clause as an aid to interpretation. An economic understanding of the MFN obligation suggests that it arises to avert certain negative externalities that would otherwise arise relating to bilateral opportunism and to erosion of the value of trade concessions. The situation prior to the UNCTAD negotiations was one in which the problems addressed by the MFN obligation had resurfaced because of a patchwork of discriminatory preferences in the trade policies of developed nations, often dating from the colonial era. The UNCTAD negotiations may be viewed as an effort to bring the attendant negative externalities under greater discipline, and the Agreed Conclusions may be seen as the embodiment of a negotiated arrangement with the following central characteristics: the developed nations agreed that they would tolerate the negative consequences for themselves associated with preferences for developing nations, at least within the agreed parameters. But they also committed themselves to ameliorate the negative consequences of discriminatory preferences for developing nations by moving toward the "generalized, non-reciprocal, and non-discriminatory preferences" contemplated by the 1971 waiver.

This understanding of the economic rationale for the UNCTAD negotiations lends further support to the conclusion of the Panel. If developed nations are allowed to engage in whatever degree of discrimination they wish without legal constraint, an essential purpose of the UNCTAD negotiations is clearly jeopardized. And even if nations are only allowed to afford differential treatment according to their assessment of the individual "development, financial, and trade needs" 
of beneficiary countries, the danger still arises that they will use such authority to justify discriminatory policies that benefit countries in favor rather than for any legitimate purpose. For these reasons, it is entirely plausible that negotiators would want to limit discrimination to fairly narrow considerations, such as status as a least-developed nation, and to forbid it otherwise.

An important counterargument must be acknowledged, however. The parties to the UNCTAD negotiations were aware of the potential political impediments to the implementation of GSP, and might well have thought that compromise on various margins, in ways not fully anticipated during the negotiations, would be mutually preferable to political impasse and the status quo ante. A 1968 Organization for Economic Cooperation and Development (OECD) report, for example, embraced the principle that "preferences should be granted to any country, territory or area claiming developing status (principle of selfelection), but preference-giving countries might decline to grant such treatment to a particular country on compelling grounds" (emphasis added). ${ }^{32}$ The scope of the term "compelling grounds" was not made clear. We cannot rule out the possibility that donor countries may have been unwilling to give much of consequence had they imagined that a tight prohibition on discrimination and reciprocity would apply going forward, and developing countries may well have been willing to take what they could get. This proposition is very much in the spirit of the argument put forward elsewhere by Robert Howse (2003), who contends that the language of footnote 3 was never intended to create a binding legal obligation.

It is also noteworthy that major GSP schemes put in place after UNCTAD II from the outset contained exemptions and restrictions that were not specifically contemplated in the Agreed Conclusions. The long list of factors that foreclose beneficiary status under US law, for example, has remained the same in large part since the Trade Act of $1974 .^{33}$ These early practices of donor countries were firmly in place at the time of the negotiations that resulted in the Enabling Clause. ${ }^{34}$

${ }^{32}$ See UNCTAD (1981, p. 21).

33 The various restrictions and limitations on the early European scheme are described at some length in Borrmann et al. (1981).

34 To be sure, some of the restrictions came under early criticism from commentators as a departure from the principles of non-discrimination and non-reciprocity. See, e.g. UNCTAD (1981, p. 39). 
Had it been the intention of the Tokyo Round negotiators to outlaw the sort of conditionality that had emerged, for example, in the US scheme devised by the Trade Act of 1974, they might well have done so more forcefully than by a somewhat oblique reference in footnote 3 to the system contemplated by the also somewhat oblique 1971 waiver.

From this latter perspective, the Appellate Body might be seen to have the better of the argument. It is certainly difficult to quarrel with its conclusion that Europe's interpretation of the phrase "developing countries" in paragraphs 2(a) and 3(c) of the Enabling Clause is a linguistically plausible one, and for the reasons noted above it is not entirely clear that the non-discrimination obligation in footnote 3 rules out any differential treatment not expressly contemplated by the Agreed Conclusions. One might even wonder whether the Appellate Body went too far in suggesting that donor countries must prove that any differential treatment is justified by reference to differences in "development, financial and trade needs." The supporters of the 1971 waiver could have anticipated that GSP schemes would contain a wide range of other conditions and restrictions to make them politically saleable in the donor countries.

In short, we concur with both the Appellate Body and the Panel in their finding that the language of the Enabling Clause is ambiguous, and is insufficient on its own to resolve the dispute. It is thus appropriate to resort to other aids to interpretation in accordance with the Vienna Convention, including the "context" of the treaty language and its "object and purpose." There can be little doubt that a central "object and purpose" of the UNCTAD negotiations was to reduce discrimination in trade preferences subject to some enumerated exceptions, and that both the 1971 waiver and the Enabling Clause may be said to incorporate this goal by reference. The approach of the Panel surely does the most to promote this objective. But we must also bear in mind that GSP benefits are a "gift" of sorts, and that donors may well have been unwilling to confer them if constrained by tight non-discrimination (and other) requirements. Developing nations may well have been aware that various forms of conditionality would be the quid pro quo, and the 1979 Enabling Clause could easily have done much more to condemn it in clear language if that was the intention of its drafters. Perhaps unfortunately, therefore, an appeal to the "object and purpose" of the Enabling Clause is also less than conclusive. 
One virtue of the Panel's approach, to be sure, is that it provides reasonably clear guidance for the future as to what is permissible and what is not. Except for the differential treatment expressly anticipated by the Agreed Conclusions, no discrimination is permissible. The approach advocated by Howse also admits of easy judicial administration, as he would find no binding legal obligation at all in footnote 3. The approach of the Appellate Body, by contrast, steering a middle course of sorts, leaves fundamental and potentially thorny questions unanswered, as the next section will indicate.

\subsection{Implications of the Appellate Body decision for other aspects of existing GSP schemes}

The Appellate Body ruling establishes two important principles: (1) footnote 3 of the Enabling Clause is a binding legal obligation, requiring "generalized, non-reciprocal, and non-discriminatory preferences;" and (2) donor countries may nevertheless afford differential treatment to beneficiary nations if it is based on differences in their "development, financial, and trade needs." These principles raise a wide array of issues to which the Appellate Body has not yet spoken.

Most obviously, what counts as a development, financial, or trade need? The Appellate Body did not rule on the question whether drug trafficking creates a "development need," finding it unnecessary to address matters on which the Panel made no finding. Yet, it seems clear that the drug-related preferences were enacted for the benefit of Europe, to reward cooperation in its efforts to reduce traffic in drugs toward Europe, rather than to assist the beneficiaries in addressing any perceived "development need" of their own. Many of the other criteria for beneficiary status found in modern GSP schemes, such as failure to aid in efforts to combat international terrorism, failure to enforce arbitral awards, or participation in a cartel such as the Organization of Petroleum Exporting Countries (OPEC), seem still farther removed from any "needs" of the beneficiary country. Perhaps incentive arrangements pertaining to labor rights and environmental protection can fit more comfortably into the rubric of "needs," but its scope remains completely open at this stage.

One also imagines that some constraint must exist on the magnitude of the differential treatment that is permissible to address 
heterogeneous development, financial, and trade needs. Even if drug trafficking qualifies as a "need," for example, could a donor country deny preferences altogether to nations that do not have a serious drugtrafficking problem while extending substantial preferences to those that do? If the differential treatment must be justified by different "needs," it would seem to follow that it cannot exceed the amount required to address any need adequately. But how would one quantify that amount or otherwise place a principled limit on it?

A related question is: do donor countries have unfettered discretion to select the "needs" that they will address through differential treatment and to ignore others? Europe limits its environmental incentives in its GSP scheme to the protection of tropical forests, for example, but suppose a nation with no tropical forest can make the case that its exceptional air pollution problem poses a greater obstacle to its development than any obstacles posed by the possible loss of tropical forest elsewhere? Would a failure to afford differential treatment to assist it in addressing its air pollution problem then amount to "discrimination?"

The puzzle as to what constitutes impermissible discrimination is only part of the bigger picture. The word "generalized" in footnote 3 refers not only to the universe of beneficiary nations, but also to the scope of product coverage. The GSP system envisioned by the UNCTAD negotiators would provide broad coverage for manufactured and semimanufactured items, limited only by quantitative ceilings or safeguard measures to address concerns about import surges. Can the complete exclusion of enumerated import-sensitive manufactured products, as in the US statute as one example, be squared with the obligation to provide "generalized" preferences?

The obligation to afford "non-reciprocal" preferences also potentially imperils much of the conditionality in modern GSP schemes. Some of those conditions, such as the US requirement that beneficiaries provide support for efforts to combat terrorism and respect arbitral awards in favor of US nationals, require reciprocity essentially on their face. Others can surely be characterized as requiring reciprocity, such as the special incentives on labor and environmental matters in the European scheme. If footnote 3 truly prohibits "reciprocity," it seemingly poses an enormous threat to the elements of conditionality that have been present in various GSP schemes since their 
inception, and that may be essential to their perpetuation as political matter. $^{35}$

In short, the Appellate Body decision puts in question many prominent features of the US, European, and other GSP schemes, features that in some cases have been part of those schemes from the outset. It invites future challenges by countries that suffer trade diversion because of discrimination or reciprocity, even perhaps by developed nations. Donor countries will have the burden to prove their compliance with the Enabling Clause since it has now been ruled to be an "exception" to GATT Art. I. That burden may prove a difficult one to carry.

If successful challenges to GSP schemes multiply going forward, it is entirely possible that donor countries will choose to forego GSP arrangements altogether. Nothing requires donor countries to maintain schemes that are no longer palatable politically, and some (including the US and European schemes) are structured to expire on their own unless the political will to renew them is present. A key question going forward, then, may be whether additional challenges will be brought as time goes on, or whether instead the interested nations will conclude that it is not in their mutual interest to rock the boat.

\section{Economic analysis}

The legal commentary in Section 2 suggests several questions about GSP schemes and their place in the multilateral trading system. Do these schemes further the development goals for which they were designed? What effect do the schemes have on the economic welfare of countries that are not granted preferential treatment? And why might the contracting parties wish to regulate the extent of differential treatment and the conditions attached by donors when, after all, the GSP schemes are "gifts" from the developed countries to their less developed trading partners?

${ }^{35}$ We note in passing another limitation on reciprocity contained in the Enabling Clause. Paragraph 5 provides, in pertinent part, that "developing contracting parties shall therefore not seek, neither shall developing contracting parties be required to make, concessions that are inconsistent with the latter's development, financial, and trade needs." Although this obligation arises in the context of "trade negotiations," GSP conditionality might be viewed as setting up a "negotiation" of sorts, and paragraph 5 would then limit the "concessions" demanded to matters not inconsistent with development, financial, and trade needs. 


\subsection{Economic effects of tariff preferences}

We begin by describing the economic effects of tariff preferences both in the country or countries that receive the special treatment and in other trading partners of the preference-granting country. Suppose first that preferences are granted to a "small country" or to a group of countries that collectively are small. In the parlance of trade theory, a small country is one that cannot affect the world prices of the goods that it trades, because its imports and exports are insignificant relative to the size of world markets. When exporters in such a country face a given world price of $p^{*}$ and an MFN ad valorem tariff rate of $t_{\mathrm{MFN}}$ they must sell their output for $p^{*} /\left(1+t_{\mathrm{MFN}}\right)$ to be competitive in the foreign market. This price prevails as well in the home market of the exporting country, because producers will not sell at home for less than what they can earn on world markets, nor will they be able to sell for more given that they choose to export at that price in a competitive equilibrium. Figure 1 shows the production and consumption levels in the exporting country prior to the time it is granted tariff preferences.

The preferences excuse the exporters in the small country from the generally applicable tariff. These exporters are too small to affect the

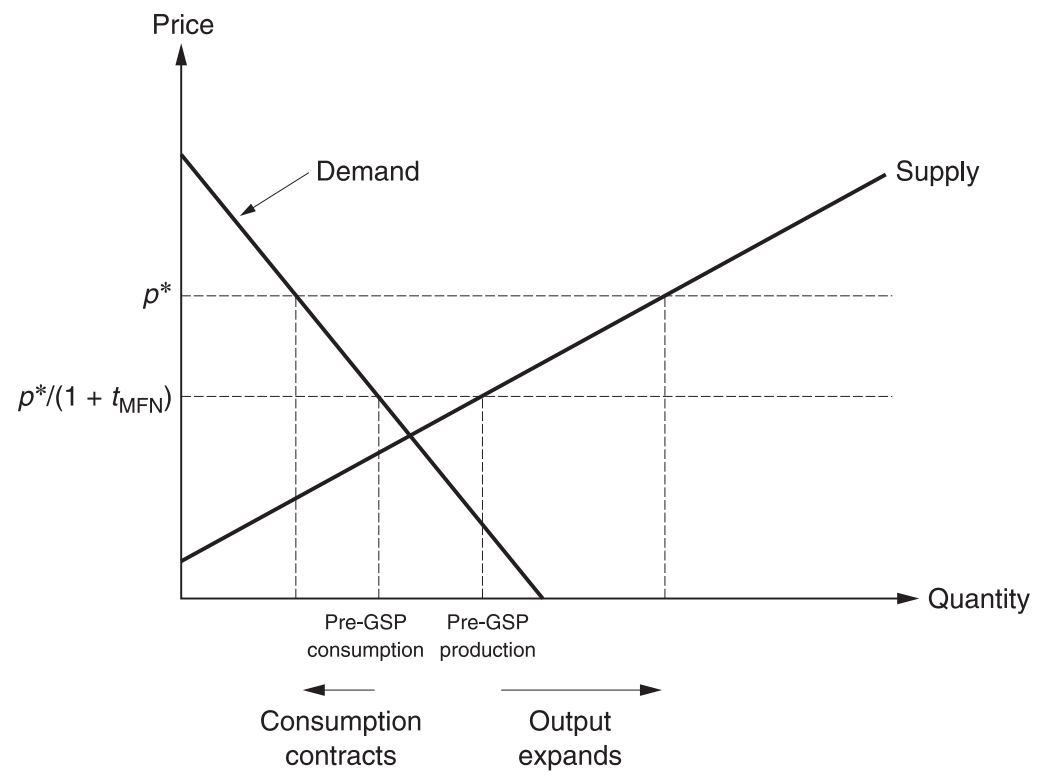

Figure 1 


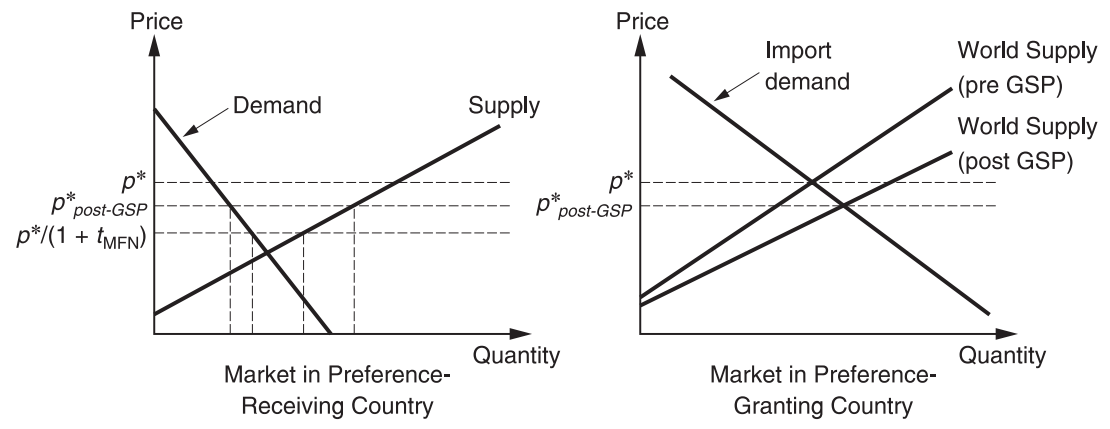

Figure 2

internal price in the preference-granting country, which remains at $p^{*}$. So, the exporters now can charge this higher amount and remain competitive in the foreign market. The figure shows that output expands as a result of the higher sales price, and that consumption in the exporting country contracts. For both reasons, exports grow.

The tariff preferences provide a "terms of trade" benefit to the exporting country. Producers gain, both because their original sales fetch a higher price, and because they expand output to the point where marginal cost equals $p^{*}$. Some of the gain to producers comes at the expense of domestic consumers, who lose surplus because they face a higher domestic price. ${ }^{36}$ But the country enjoys a net gain in welfare equal to the trapezoidal area between the supply and the demand curves and bounded by $p^{*}$ and $p^{*} /\left(1+t_{\mathrm{MFN}}\right)$. Note that the price for exporters in countries that do not receive the preferential treatment remains at $p^{*} /\left(1+t_{\mathrm{MFN}}\right)$. Thus, all growth in trade due to the GSP reflects trade creation; the other (small) countries that export to the preference-granting country suffer no harm in this case.

Now suppose that preferences are granted to a large country or to a group of countries that collectively is large. This situation is depicted

${ }^{36}$ Our analysis is predicated on the assumption that the prevailing tariff in the country that receives preferential treatment is greater than the MFN tariff in the country that grants the preferences. This assumption is reasonable in most cases, as average rates of protection are much higher in developing countries than in developed countries. If the assumption is violated, the preference-receiving country would export all of its industry output at price $p^{*}$, while domestic consumers would be served by imports from thirdcountries, where the prevailing price is $p^{*} /\left(1+t_{\mathrm{MFN}}\right)$ and so the tariff-inclusive import price would be less than $p^{*}$. In the event, the terms of trade gain for the preferencereceiving country is even larger than that described here, but it remains true that the preferences generate no negative externalities for third countries. 
in Figure 2. As before, the granting of preferences will tend to raise the internal price in the preference-receiving country, as shown on the left-hand panel. But now the impact of the export growth on the world price cannot be ignored. The right-hand panel shows that total world supply to the donor country has expanded, which means that the market clearing price falls from $p^{*}$ to $p^{*}$ post-GSP. The preferencereceiving country still enjoys a terms-of-trade gain, but not as great as before. ${ }^{37}$ Welfare rises by the (smaller) area bounded by the demand and supply curves and by the price lines $p^{*} /\left(1+t_{\mathrm{MFN}}\right)$ and $p^{*}$ post-GSP.

In this case, the export growth in the preference-receiving country reflects both trade creation and trade diversion. The trade creation is reflected in the fact that the GSP reduces the internal price in the preference-granting country, so its consumption expands and its home production contracts. The reduction in its home production is (more than) made up by its imports from the preference-receiving country. But the fall in the world price produces a terms-of-tradeloss for other countries that export to the preference-granting country. These countries see their exports displaced in part by goods from the preference-receiving country. They also earn less from what they do sell, and their welfare falls. In this case, the GSP imposes a negative externality on the exporting countries that do not qualify for the preferential treatment. ${ }^{38}$ It is this negative externality that might explain why a country like India would object to the European GSP scheme. ${ }^{39}$

\subsection{Does GSP promote “development?"}

The Preamble to the 1971 Waiver, which provided the initial authority for tariff preferences that would otherwise violate GATT Art. I,

37 The computational results presented by Brown $(1987,1989)$ show terms of trade gains from US and European GSP schemes for most beneficiary countries.

${ }^{38}$ Limão (2005) identifies another (political) economic externality that may result from tariff preferences. He points out that if the developed countries see their GSP schemes as a means to elicit cooperation from developing countries on non-trade issues, then the existence of these schemes may impede multilateral trade liberalization. The developed countries might regard their MFN tariff cuts as eroding the preferences afforded by their GSP schemes and thus limiting their ability to induce cooperation from their trading partners. Limão provides evidence that US tariff reductions in the Uruguay Round were smaller for goods imported on preferential terms than for similar goods that were not imported from favored partners.

${ }^{39}$ We also duly note the fact that the drug-related preferences in the European scheme extended to Pakistan and not to India, a situation that India may have found objectionable for political reasons. 
states "... that a principle aim of the Contracting Parties is promotion of the trade and export earnings of developing countries for the furtherance of their economic development." To what extent can tariff preference schemes promote trade and export earnings for the furtherance of economic development? We address this question in the light of our brief analysis of the economic effects of tariff preference schemes.

As our analysis has shown, the granting of tariff preferences does serve to promote trade volume and export earnings in the preferencereceiving countries. The magnitude of this effect for existing GSP schemes is a matter of some debate, but a consensus view might be that the revenue gains have been modest but not trivial. ${ }^{40}$ Surely the gains could be larger but for the many product exclusions that the preference-granting countries have introduced to minimize pain to their own import-competing industries. But whatever their precise magnitude, the terms-of-trade gains provide a form of "development aid" inasmuch as they boost incomes for owners of export concerns and quite possibly for factors of production such as unskilled labor that are used intensively in export sectors in the developing countries. In this sense, the GSP schemes can be seen as serving their putative purpose.

Arguably, however, the contracting parties had more in mind. UNCTAD Resolution 21(ii) also made reference to a desire to promote industrialization and economic growth. To the extent that tariff preferences raise producer prices in the developing countries, they do encourage greater output of the eligible goods than would take place in their absence. However, production of those goods entails an opportunity cost, and it is hardly clear that GSP arrangements encourage the expansion of the industries that will do the most to promote economic growth over the long haul. That might prove to be the case if, for example, the export activities encouraged by the GSP schemes are "infant industries" subject to positive learning externalities. Given the many product exclusions and limitations in the existing GSP schemes, however, it would be a fortunate coincidence if the products that are eligible happened also to be the ones that generate learning spillovers. Likewise, given the way that donor nations exclude import-sensitive items from tariff preferences and otherwise "graduate" successful

${ }^{40}$ Sapir and Lundberg (1984), Karsenty and Laird (1986), and MacPhee and Oguledo (1991) all find modest gains in export volume and export earnings for beneficiaries of the GSP schemes. They find, however, that these gains are highly concentrated in a few, higher-income developing countries. Brown $(1987,1989)$ draws similar conclusions from a computable general equilibrium model. 
industries and countries, one wonders whether the industries that offer the best opportunities for "growth" to developing countries are not precisely the ones in which preferences will never be offered, or where they will be withdrawn once signs of industrial success appear. Certainly, there have been no empirical studies to suggest that GSP schemes have promoted "growth" beyond simply conferring some rents on selected industries as described above.

Moreover, the benefits of tariff preferences are diminished in practice by compliance costs. ${ }^{41}$ The available evidence suggests that many goods imported from developing countries that appear to be eligible for preferences do not receive them. UNCTAD (1981) concluded, for example, that the "utilization rate" for various GSP schemes - the ratio of imports actually receiving preferential treatment to the total imports that are eligible under each scheme - was under 50\% for the US and European programs and barely over 50\% for Japan. One reason given for the low ratios, though not the only reason, was the "difficulties which arise in complying with the rules of origin and other requirements of the schemes." ${ }^{42}$ UNCTAD (1999) notes a further decline in utilization rates for some of the schemes, owing partly to an "erosion of preferences which in some cases are too low to compensate for the cost of compliance." Even in the cases in which preferences are obtained, compliance costs reduce their value.

The benefits from tariff preferences will be further diminished (or even become negative) if they lead to overinvestment in the sectors that are eligible for preferential treatment. After all, the very nature of a preference is to encourage the expansion of output to a level that would not be economical in the absence of the preference. The possibility that preferences may then distort investment decisions, rather than encouraging investment where long-term growth opportunities are present, has been noted elsewhere. ${ }^{43}$ One reason to be concerned about such overinvestment is that preferences have often proven to be temporary, as product coverage and rules about conditionality and graduation have changed over time. See UNCTAD (1999). If the

${ }^{41}$ Keck and Low (2004) make a similar point in the course of their broader review of special and differential treatment, and mention several other considerations that we also note as limiting the benefits of GSP to developing countries.

${ }^{42}$ For a survey of the various approaches to the rules of origin in GSP schemes, see Chapter 6 in Murray (1977).

${ }^{43}$ See, for example, Finger and Winters (1998), who write that "preferences...permit perhaps encourage - producers to have costs above those in nonpreferred countries." 
private sector invests on the expectation that the preferences will be long-lasting, then there may be severe resource misallocation once the preferences are removed. Of course, such a misallocation of resources should not be a problem - at least for the country that is granted preferential treatment - unless the investors misjudge the likely duration of the GSP schemes, the likelihood of changes in their rules and product coverage, or the likelihood that the MFN tariff will fall (in short, an absence of "rational expectations"). But misjudgment is a real threat given all of the moving parts and the fact that the GSP programs are modified quite regularly.

Finally, there is some evidence in recent research that the benefits to developing countries from GSP schemes may be limited for another reason. Özden and Reinhardt (2003) argue that preferential tariff treatment may retard trade liberalization in beneficiary countries. This might be so because GSP preferences can reduce the incentive that export industries in developing countries have to lobby for trade liberalization at home as a means to garner market access abroad. Import liberalization by developing countries will also shift resources from import-competing to exporting sectors in those countries and may hasten the withdrawal of the preferences as their export sectors bump up against "competitive need" and graduation provisions under the GSP schemes. Export interests in developing countries may harbor mixed feelings about trade liberalization at home for this reason as well. Özden and Reinhardt examine empirically the effect that GSP removal (as through "graduation") has had on former beneficiaries' trade policies and find that countries that lose their eligibility for GSP subsequently undertake greater liberalization than those that retain their eligibility. Some studies suggest, furthermore, that developing countries with more liberal trade policies achieve higher rates of growth and development than countries that are more protectionist. ${ }^{44}$ If Özden and Reinhardt are correct in their empirics, therefore, we have yet another reason to worry that the effects of GSP on growth and development may be less favorable than one might hope.

To summarize, there are no good estimates of the aggregate benefits that developing countries derive from the GSP schemes.

${ }^{44}$ See, for example, Dollar (1992), Sachs and Warner (1995), Edwards (1993), and Frankel and Romer (1999). These studies are not without their critics, however, and some like Rodriguez and Rodrik (2001) and Hallak and Levinsohn (2004) have questioned whether there really is evidence of a positive relationship between openness to trade and growth. 
Economic theory predicts an improvement in the terms of trade on eligible products, which may be smaller than the preference margin if the developing countries collectively are large in the markets for their exports and so depress world prices as they expand their exports. Benefits beyond the pure terms-of-trade gain are possible if the export industries happen to be ones that generate positive learning spillovers, but there is no evidence to suggest that products included in existing GSP schemes are more worthy of encouragement than others. Compliance costs associated with rules of origin and the like surely cut into the potential beneficial effects of GSP as well, and exclusions of products deemed "sensitive" in the donor countries have done so to an even greater extent. Finally, GSP schemes may have encouraged overinvestment in sectors that will prove only temporarily eligible and may have retarded the process of trade liberalization in the eligible countries. For all these reasons, the benefits generated by tariff preference schemes, while perhaps positive, are likely to be reasonably small.

\subsection{Differential treatment and conditionality in tariff preference schemes}

Whatever economic analysis has to say about the likely benefits of trade preferences in general, the members of the WTO evidently believe that tariff preference schemes do generate benefits for the favored countries and that these benefits are sufficient to justify a departure from the MFN principle. The question raised by India's challenge to the European drug-related preferences is not whether the gains generated by GSP justify the distortions that it creates, but rather what sort of discrimination within GSP schemes ought to be tolerated.

One might wonder why the members of the WTO would choose to regulate GSP at all. After all, such schemes represent unilateral "concessions" made by the developed countries to further the "development, financial, and trade" needs of a group of developing countries. Shouldn't a donor have the right to set the terms of his gift and specify the beneficiaries? Don't the developing countries have the choice whether to meet the conditions or not?

To address these questions, it is necessary to make some assumptions about the objectives of the WTO Agreement. Like Bagwell and Staiger $(1999,2002)$ and Grossman and Mavroidis (2003), we believe 
that the purpose of trade agreements is to limit the negative international externalities that countries create when they set their trade and industrial policies. An externality can arise when a welfaremaximizing government sets a positive tariff to improve its national terms of trade. But one need not accept that governments maximize national economic welfare as conventionally defined to conclude that agreements are meant to solve problems of international externalities. Sovereign governments can and do routinely undertake policy actions that do not promote aggregate national welfare. But their trading partners have no reason to interfere in these policy choices unless they suffer some harm as a result. Similarly, when two (or more) countries strike a bilateral (or plurilateral) agreement, non-parties to the agreement have no interest in it as long as the agreement does not adversely affect their interests. But policy choices, including decisions about trade policy, often do have external consequences. Without some sort of multilateral agreement encompassing all of the affected parties, countries will set their policies and conclude agreements without regard for the harm done to others, leading to an equilibrium from which a Pareto improvement is possible with the aid of multilateral rules. The law of the WTO can be understood as a mechanism to ensure that international externalities are taken into account.

If the objective of international agreements is to limit negative externalities, we can see why the WTO Members might wish to regulate GSP. As we have discussed, when a country affords preferential treatment to a group of countries that collectively are large in the market for some good, the effect is to lower the world price of that good and to generate a terms-of-trade loss for other countries that export the same or a similar good. A GSP scheme that targets certain countries for special treatment can bring harm to others that are not so favored. And a scheme that offers preferential treatment only when specified conditions are met can reduce welfare for those that choose not to fulfill the conditions.

The arguments for limiting differential treatment in the GSP schemes parallel those that have been made by economists and legal scholars to justify the MFN rule in GATT Art. I. Schwartz and Sykes (1997) argue that the MFN rule addresses a potential problem of concession erosion. Suppose country B receives a concession from country A in the course of a trade negotiation, and that country B is not entitled to MFN treatment from country A. Then, the value of the concession could 
be undermined by a subsequent agreement between country A and country $\mathrm{C}$ that provides the latter with even better terms than were granted to country B. Anticipating this possibility, country B would offer less for the concession from country A, and less trade liberalization would result. Thus, the MFN rule helps preserve the incentives for trade liberalization through international negotiation.

Bagwell and Staiger $(2002,2004)$ point to the related concept of bilateral opportunism. Suppose countries A and B import a common good from country $\mathrm{C}$ and export another good to that country. Suppose further that the three countries have reached an initial agreement that is jointly efficient, in the sense that no change in tariffs can increase the welfare of one government without reducing the welfare of another. ${ }^{45}$ Then, in the absence of MFN, the governments of country $\mathrm{A}$ and $\mathrm{C}$ can always find another deal that benefits themselves at the expense of country B. As Bagwell and Staiger show, these countries can reduce the tariffs they apply to one another's goods in such a way that their multilateral (or weighted average) terms of trade do not deteriorate; the terms of trade loss each suffers from lowering a tariff is at least offset by the terms of trade gain each enjoys from improved access to the other's market. But the reduction of country C's tariff on imports from A induces trade diversion from competing country $\mathrm{B}$ and so harms that country. And the reduction of country A's tariff on imports from C expands world demand for C's export good, which spells a further loss for country B. Evidently, in the absence of MFN, countries A and $\mathrm{C}$ may be tempted to strike a deal that benefits each of them at the expense of the excluded country B.

Bagwell and Staiger go on to show that an MFN rule makes it more difficult for a pair of countries to engage in bilateral opportunism. With non-discrimination, country $\mathrm{C}$ must offer the same concessions to country B as it offers to country A. Thus, it cannot offer to "pay for" a tariff reduction by country A with a policy change of its own that benefits country A by diverting imports to it that would otherwise come from country B. Indeed, when the MFN rule together is combined

${ }^{45}$ Welfare here may be national economic welfare, if the governments are benevolent welfare maximizers, or more generally political welfare that includes other objectives besides just conventional economic welfare. 
with strict adherence to the principle of "reciprocity," the scope for bilateral opportunism behavior is eliminated entirely. ${ }^{46}$

Similar problems of concession erosion and bilateral opportunism can arise in a trade regime that admits differential treatment in GSP. Suppose developed country A makes a concession to developing country $B$ in the course of a trade negotiation. If country A subsequently offers reduced tariffs to developing country $\mathrm{C}$, but not to country $\mathrm{B}$, this can erode the value of the earlier concession to country $\mathrm{B}$. As a consequence, country B may value the original concession less highly and so will have less incentive to open its own markets. As for bilateral opportunism, suppose that developed country A considers developing country B to be its friend and ally. By providing preferential access to its markets, country A generates economic gains for its ally while furthering its own political ends. Now if country A can do so selectively (by excluding "sensitive products") and discriminatorily (by making developing country C ineligible), then country A can ensure that there are few political costs at home, and that most of the gains to country B come at the expense of other countries, especially countries whose exports are similar to those of country B, such as developing country C.

Bagwell and Staiger (2002) have argued that the provisions of international trade agreements are intended to diminish or eliminate the scope for negative international externalities, and that agreements ought to be designed with this goal in mind. This perspective, with which we concur, points to a strict interpretation of footnote 3 of the Enabling Clause as a binding obligation for developed countries to treat all developing countries similarly in the GSP schemes, except for the permissible special treatment of the least-developed countries. However, we recognize that such an interpretation might well have a chilling effect on the willingness of developed countries to offer GSP benefits, which after all are unilateral concessions and not negotiated as part of any trade agreement. The political realist must ask whether eliminating the

${ }^{46}$ Bagwell and Staiger define reciprocity in GATT as the principle that changes in trade policy should leave world prices unchanged, or else those who effect the changes in world prices must compensate those who are harmed by it. The MFN rule ensures that each country faces a common terms of trade (relative price of imports compared to exports) and not a different terms of trade with each partner. Thus, strict adherence to principles of MFN and reciprocity would imply that any bilateral deal between countries A and C does not change the relative prices faced by each country, and, as such, does not cause any harm to that country. 
scope for negative externalities is worth the cost of fewer "donated" GSP schemes. Once this trade-off is recognized, it becomes difficult to say how much differential treatment should be tolerated and under what circumstances. Economic analysis can highlight the trade-off, but only empirical and political analysis can determine the magnitude of likely negative externalities on the one hand, and the likely political response to stricter regulation of GSP on the other.

One other issue warrants brief mention. The externalities associated with trade policy are not the only externalities from global interaction. Pollution that damages the global commons or that simply crosses borders affords another class of examples, as do the costs and benefits that arise because of interdependent utilities across nations. (Indeed, GSP itself might be seen to result from an altruistic concern for the less fortunate.) One might argue that the negative externalities associated with discriminatory GSP schemes should be tolerated if discrimination nevertheless aids in addressing these other sorts of externality problems but there is an obvious difficulty with this line of argument. If preferential treatment is used to address alleged negative externalities, who among the WTO Member states should decide what constitutes a negative externality and how large its magnitude is? We see no principled way to discipline a process in which each nation decides for itself what "externalities" to address through discrimination or reciprocity. And absent any discipline, the danger of a return to the pre-UNCTAD days of widespread discrimination is apparent. If discrimination and reciprocity are to be permitted, therefore, we question whether they can be justified convincingly by a need to address other "externality" problems. Instead, the justification likely lies in the need to make GSP politically saleable in the donor countries, bringing us full circle to the set of trade-offs identified above.

\section{References}

Bagwell, K. and Staiger, R. W. (1999). An Economic Theory of GATT, American Economic Review 89, 215-248.

Bagwell, K. and Staiger, R. W. (2002). The Economics of The World Trading System, Cambridge, MA and London: The MIT Press.

Bagwell, K. and Staiger, R. W. (2004). Multilateral Trade Negotiations, Bilateral Opportunism and the Rules of GATT, Journal of International Economics 63, $1-29$. 
Borrmann, A., Borrmann, C. and Steger, M. (1981). The EC's Generalized System of Preferences, The Hague: Martinus Nijhof Publishers.

Brown, D. K. (1987). General Equilibrium Effects of the US Generalized System of Preferences, Southern Economic Journal 54, 27-47.

Brown, D. K. (1989). Trade and Welfare Effects of the European Schemes of the Generalized System of Preferences, Economic Development and Cultural Change 37, 757-776.

Dollar, D. (1992). Outward-Oriented Developing Economies Really Do Grow More Rapidly: Evidence from 95 LDC's, 1976-85, Economic Development and Cultural Change 40, 523-544.

Edwards, S. (1993). Openness, Trade Liberalization, ad Growth in Developing Countries, Journal of Economic Literature 31, 1358-1393.

Finger, J. M. and Winters, L. A. (1998). What Can the WTO Do for Developing Countries? In A.O. Krueger, ed., The WTO as an International Organization, Chicago: The University of Chicago Press, pp. 365-392.

Frankel, J. A. and Romer, D. (1999). Does Trade Cause Growth, American Economic Review 89, 379-399.

Grossman, G. M. and Mavroidis, P. C. (2003). United States - Imposition of Countervailing Duties on Certain Hot-Rolled Lead and Bismuth Carbon Steel Products Originating in the United Kingdom: Here Today, Gone Tomorrow? Privatization and the Injury Caused by Non-Recurring Subsidies. In H. Horn and P.C. Mavroidis, eds., The WTO Case Law of 2001, Cambridge: Cambridge University Press, pp. 170-200.

Hallak, J. C. and Levinsohn, J. A. (2004). Fooling Ourselves: Evaluating the Globalization and Growth Debate, NBER Working Paper No. 10244, Cambridge, MA.

Howse, R. (2003). India's WTO Challenge to Drug Enforcement Conditions in the European Community Generalized System of Preferences: A Little Known Case with Major Repercussions for "Political" Conditionality in US Trade Policy, Chicago Journal of International Law 4, 385-405.

Karsenty, G. and Laird, S. (1986). The Generalized System of Preferences: A Quantitative Assessment of the Direct Trade Effects and of Policy Options, UNCTAD Discussion Paper 18, UNCTAD, Geneva.

Keck, A. and Low, P. (2004). Special and Differential Treatment in the WTO: Why, When and How?, WTO Staff Working Paper ERSD-2004-03.

Limão, N. (2005). Preferential Trade Agreements as Stumbling Blocks for Multilateral Trade Liberalization: Evidence for the US, Centre for Economic Policy Research Discussion Paper No. 4884, London UK.

MacPhee, C. R. and Oguledo, V. I. (1991). The Trade Effects of the US Generalized System of Preferences, Atlantic Economic Journal 19, 19-26.

Murray, T. (1977). Trade Preferences for Developing Countries, New York: John Wiley and Sons. 
OECD Secretary General, (1983). The Generalized System of Preferences: Review of the First Decade, Paris: Organization of Economic Cooperation and Development.

Özden, Ç. and Reinhardt, E. (2003). The Perversity of Preferences: GSP and Developing Country Trade Policies, 1976-2000, World Bank Working Paper 2955, The World Bank.

Rodríguez, F. and Rodrik, D. (2001). Trade Policy and Economic Growth: A Skeptic's Guide to Cross-National Evidence, NBER Macroeconomic Annual 15, 261-324.

Sachs, J. D. and Warner, A. M. (1995). Economic Reform and the Process of Global Integration, Brookings Papers on Economic Activity 1, 1-95.

Sapir, A. and Lundberg, L. (1984). The US Generalized System of Preferences and its Impacts. In R. E. Baldwin and A. O. Krueger, eds., The Structure and Evolution of Recent US Trade Policy, Chicago: The University of Chicago Press, pp. 195-231.

Schwartz, W. F. and Sykes, A. O. (1997). The Economics of the Most Favored Nation Clause. In J. S. Bhandani and A. O. Sykes, eds., Economic Dimensions of International Law: Comparative and Empirical Perspectives, Cambridge: Cambridge University Press, pp. 34-79.

UNCTAD (1981). Operation and Effects of the Generalized System of Preferences, Fifth Review, New York, United Nations Conference on Trade and Development.

UNCTAD (1999). Quantifying the Benefits Obtained by Developing Countries from the Generalized System of Preferences, New York, United Nations Conference on Trade and Development. 